\title{
Effect of Dialogic Teaching on Pedagogy at Intermediate Level in District Bannu
}

\author{
* Ihsan Ullah Khan, Assistant Professor \\ ** Dr. Abdul Hamid Khan, Head of the Department
}

\begin{abstract}
This study aims at finding the effect of dialogic teaching on pedagogy. Dialogic teaching is based on Bakhtin's concept of 'Dialogism'. Data were obtained from an experimental study that was conducted on $12^{\text {th }}$ grade students of a public sector college in District Bannu. The researcher reflected back on the interaction with the students, whose philosophies brought major changes in language pedagogy, that is why Coia and Taylor's (2009) "Self-study method of Co/autoethnography" was referred to as the reference in the study. Data revealed that valuable addition was made to the researcher's language pedagogy by engaging in a philosophical dialogue with the students. Being dialogic, the teaching method not only can improve learners' efficiency to communicate effectively in the target language, but also prove that the learners are co-creators of knowledge in the classroom; in the light of which teachers may re-shape their language pedagogy.
\end{abstract}

Keywords: Bakhtin; Dialogism; Dialogic Teaching; Language Pedagogy; Co-creator Introduction

Our pedagogy is greatly influenced by our students, though they are no longer present physically around us. Across the space and time, we are constantly engaged in dialogue with other people through our utterances (Stewart \& Greg, 2013). Thus our activities are shaped by such interactions with other people and our past experiences. The Bakhtinian concept of polyphony also supports this notion which contends that such ideas and utterances cannot exist separately; hence, we cannot make a whole claim for such utterances. Bakhtin's theory of language backs up the notion that our language pedagogy is shaped by the voices of our students that recur in our thoughts regularly. Dialogue, according to Freire (2004), prevents us from wasting our energies in segregation and enables us to create space for other people's influence on our lives. Dialogic teaching, derived from Bakhtin's concept of 'Dialogism', has very positive impact on our language pedagogy. It has a positive impact as the teachers can clearly feel the voices of their students in their mind whenever they look in retrospect, because there is a harmony between the voices of students and some other elements present in that situation (Bakhtin 1981). Schoen (1987), also holds the opinion that our present performances are greatly influenced by reflecting on our past incidents. The meaning-making process takes place in a classroom when a connection is built up between teachers and students through lived experiences (Freire, 1970; Hooks, 1994). Russell (2010), is of the view that students are the storehouse of knowledge, though incomplete, and it is not right to think about them as merely empty vessels which should be filled with information. The influence of students on teachers' language pedagogy, in dialogic teaching, cannot be ignored as there is a sharing in the power of making decisions between teachers and students (Stewart 2013). Several researchers (Calderhead (1989); Korthagen and Vasalos, (2005)) contend that teachers' language pedagogy is greatly improved when they reflect back on their past practices. Teachers are engaged in dialogue, through polyphonic pedagogy, with the current as well as former students. The individual voices are constantly engaged in dialogue with others through text or speech (Bakhtin (1981); Bakhtin (1986); Holquist (2002), as quoted in Hepple (2010).

\section{Objectives of the Study}

One of the main objectives of the study was to check the effectiveness of dialogic teaching in bringing positive changes in pedagogy of ESL teachers.

\section{Research Questions}

The study aimed at finding answer to the following research question:

\footnotetext{
* Department of English and Applied Linguistics, University of Science and Technology Bannu, Khyber Pakhtunkhwa, Pakistan Email: ihsanlakki@yahoo.com

** Department of Linguistics and Literature; Qurtuba University of Science and Information Technology, Peshawar, Khyber Pakhtunkhwa, Pakistan
} 
1. What changes are brought about by dialogic teaching in pedagogy at intermediate level in District Bannu?

Significance of the Study

Dialogic teaching will prove very beneficial for those ESL teachers who are in search of resultoriented method of teaching. The traditional methods of teaching English is producing results, neither for students nor for teachers. What is promoted by the traditional methods of teaching among the students is rote learning. English language teachers also gain nothing from their boring lectures as, like newscasters, they deliver lecture and get no response from their students. Dialogic teaching, on the other hand, will prove very helpful, both, for students as well as teachers; as meaning-making process takes place for both the parties. As teachers, in dialogic teaching, are constantly in dialogue with the students, this practice contains much food for teachers' future career. It is fact that not only students learn from teachers but teachers also get a lot from their daily discourses with their students. This learning, for teachers, is guaranteed more by dialogic teaching than any other method. The reshaping of language pedagogy, as a result of dialogic teaching, will go a long way for ESL teachers in achieving their teaching goals.

\section{Literature Review}

The purpose of the study was to check the effectiveness of dialogic teaching in bringing visible changes in the language pedagogy of ESL teachers. The concept of dialogic teaching has been derived from Bakhtin's 'dialogism'. Stewart \& Greg (2013), provided great inspiration for the study. Following are discussed, briefly, the concepts of Bakhtin's dialogism and dialogic teaching.

\section{Dialogism}

According to Hall, et al., (2005, p. 2) dialogism and other ideas were developed by Bakhtin in response to early Russian formalists. The term 'dialogism' was used by Bakhtin $(1981,1986)$ to explain the relationship between the utterances of speaker with the utterances of other speakers with whom one enters into discussion. In Bakhtin's conceptualization of language, an important concept is that of an utterance. Utterance is the concrete response we give to the condition of the moment. As utterance is two-sided act; it, on one hand, responds to what precedes and, on the other, it anticipates what is to come. Thus, while we speak, the utterance belongs to the context of use which was created during speaking. The term 'speech genre', used by Bakhtin is all about the utterances. A speech genre is a typical form of utterance rather than a form of language. Genres, in this sense, corresponds to particular contacts between the meanings of words. At the moment of use of genres, they are infused with our own voices. The term 'dialogic' was used by Bakhtin to capture the meaning-making process through utterance. As utterances occur in a specific context, they cannot be considered as individual act.

\section{Dialogic Teaching}

Gupta and Lee (2015) consider dialogic teaching as a technique in which teachers achieve their learning goals and help the learners in accomplishing their tasks through dialogues. Alexander (2008), is of the opinion that contrary to traditional ways of teaching; dialogic teaching makes the students inquisitive. It trains them not to give, merely, set answers, rather empowers them to speculate, explore, evaluate, imagine, explain, narrate, and analyze. In ELT, for the teachers who are in search of suitable alternatives to change their current teaching methods with the more effective ones, a sound foundation can be presented by the Bakhtinian view of language and his theories of literature. According to Stewart (2010), the role of dialogue for instructional activities is very important. It will prove helpful in providing a theoretical framework for teaching in which L2 learners are active participants rather than passive receivers of information. In the words of Bakhtin (1986), the 'meaning-making' process in English language classrooms can effectively be completed when authentic dialogue is made a compulsory part of classroom teaching. Active responsive understanding, in the words of Bakhtin, is achieved through authentic dialogue. In this process teachers and students, together, construct knowledge. It is possible to construct knowledge collaboratively when the unique worldviews, brought by the learners to classroom, is understood by the teachers. Stewart (2010) is of the view that words, spoken by people; gain meaning as they have their histories like the speakers, who speak the words, have their histories. In the teaching-learning process, too, the voices of teachers and learners create histories when they engage in dialogue. 


\section{Methodology \\ Data Collection}

Data for the present study were collected from the experimental study which was carried out in a public sector college in District Bannu Total 62 inter-level students $\left(12^{\text {th }}\right.$ grade $)$ were selected and were divided into two equal groups. For the equal distribution of the students in each group, their division was made on the basis of pre- test. The suitability of 30 respondents for starting the basic statistical procedure is supported by Grinnell and Williams (1990, p. 127) and Seaberg (1988, p. 254). 'Control group' and 'treatment group' were the terms used for both the groups respectively. The selection of the groups was made on random basis. Keppel and Wickens (2003), believe that equality between the groups is maintained due to the random selection of the groups. Rosenthal \& Rosnow (1991) hold the opinion that normally two or more than two groups are tested in the experimental studies. The three students, whose experiences are shared in the study, belong to treatment group.

\section{Mode of Data}

An important factor in research and teaching is the process of reflecting back on the interaction with the students, whose philosophies brought major changes in our teaching pedagogy. For this purpose, the researcher referred to Coia and Taylor's (2009) "Self-study method of Co/autoethnography.

\section{Analysis and Discussion}

For the analysis of data, the experiences during the experimental study were converted into notes. From those notes categories and themes were generated. Major themes were reflected by the students, described in the following lines. Teachers teach new students in the classroom, and, very soon, these students become history; replaced by other students and the process goes on. They are hardly aware of the influences those students have on their language pedagogy. However, students do have influence on teachers' language pedagogy, which is re-shaped by them time to time. It happens when a teacher reflects back and engages in dialogue with former students. It happened to the researcher as well, after the experimental study was over. When the experimental study was over and he reflected back on his past experience, he felt the influence of many students on his language pedagogy; nevertheless, the most prominent among them were the following students. The names described are their pseudonyms. The experience with those students is shared below:

\section{Bakht}

Dialogic teaching proved instrumental in bringing visible changes in the researcher's language pedagogy. Of all the students who took part in the experimental study, none has influenced my language pedagogy more than Bakht. All the students were learning English as their second and foreign language. During the study an assignment was given to the class in which all the participants were supposed to write a paragraph, describing their strong and weak areas. This practice is supported by Tomlinson (1999), who believes that effective way of starting the business in classroom is to ask the students tell about their strengths and weaknesses in the shape of autobiography. Different students responded in different ways, but an interesting response was given by Bakht. He recorded that his greatest weakness was the moment when he got an individual attention from the researcher, during one of the classes in the experimental study. "I cannot explain in words, how happy I was when you pronounced my name while discussing a matter with me!", he added. Although this couldn't be a weakness but he tried to convey that the act of pronouncing his name before the whole class created a great excitement in his thoughts. The extent to which Bakht was impressed by the act was quite new and surprising for the researcher. Hindman et al, (2004) are of the opinion that effective teachers know the strengths and weaknesses of their students as, like every individual, every student is also unique; bringing different interests to classrooms different strengths and weaknesses. A single sentence of the student taught me a whole new thing that had food and nourishment for future. (Wright, Horn, and Sanders, (1997), are of the view that effective teachers, by adjusting the instructional strategies according to the interests of their students, can maximize their level of achievements. Tomlinson (1999), believes that, basically, every teacher is a learner and s/he learns best when s/he knows the strong and weak areas of his/her students. Glenz (2014), holds that, in order to make the students realize their own existence and importance, teacher must remember their names and pronounce them with their names. Syverud (1993) believes that even teachers themselves would term those teachers as their best teachers who used to pronounce their names in the classroom 
It was a dialogue through space and time, with the old students, which gave the researcher's language pedagogy a new dimension. Freire (1970) is of the view that a concrete situation is necessary for starting an educational program, and this incident presents a concrete situation for the researcher. The researcher always feels the presence of Bakht, which forces the researcher to continue the practice of addressing students with their names; whenever he enters a new class for teaching. The lesson learned can never be forgotten in the future as well.

\section{Usman}

An incident that took place during the experimental study, which evoked thought provoking feelings in the researcher's mind, was the dialogic conversation with Usman. In one of the writing assignments he recorded that having no control over his anger was one of his greatest weaknesses. When he got angry, he did not care about anybody, even his own parents. In that fit of anger he offended his parents. He used to cry in repentance when he came back in his senses. He doubted everything, even his own religion, under the influence of that weakness. "It happened quite regularly", he added. The views were quite shocking as they came from a student whose academic record was excellent. On inquiring Usman disclosed that he reads the books of philosophy and, most probably, the problem was created by those books. It seemed that the books were not of his level and he could not get the real message from them. This was totally an unexpected situation. "How could a student of $12^{\text {th }}$ grade be adversely affected by books of philosophy", I wondered. Equally surprising for the researcher was the fact that students of his level, in the context of District Bannu, were reading such books. The problem was there and the problem needed to be solved as it was not wise to leave him to his own state. The researcher, following the dialogic process in the shape of written drafts, started communication with him. He felt quite relaxed at the end of the experimental study and was very grateful. The importance of psychology, as a subject, for a teacher was realized at that crucial moment by the researcher. It was realized that sufficient knowledge of psychology was necessary for a teacher. In the absence of such knowledge the lives of bright students may be ruined. The knowledge of psychology is necessary as, according to Alaji et al., (2015), the behavior is studied scientifically through psychology. Patrick et al., (2011), believe that educational psychologists have a thorough knowledge of classroom management and assessment; and children's development, motivation are the essential components of effective teaching. Result-oriented and effective teaching takes place when teachers are equipped with thorough knowledge of students' motivation, learning, and their development (Zumwalt \& Craig, 2005).

\section{Sabir}

Sabir was another bright student among the participants of the experimental study. As an effort and, in accordance with a premeditated activity, to improve the learners' English language writing skill, an assignment of writing a paragraph was given to the class. The students were supposed to write about their feelings, what they themselves would have done if they had been English teachers. Sabir recorded his own experience in the assignment. According to him, few things were very boring while writing in L2. One among them was the fear of committing mistakes and, thereby, getting low grades; and the second was writing on traditional academic topics. He recorded that on becoming an English teacher, he would, first of all, remove from the minds of his students the fear of committing mistakes. He would ask the students to consider writing in L2 as fun. Secondly, for writing practice, he would have induced his students to write on subjects which were not traditional and in which they took interest. It was surprising for the researcher to read what was going in the students' mind. His views are in line with those of Stewart (2013), who believes that the first success of an English teacher is to force students to put pen to paper. Celce Murcia (1991), indicates that several problems are faced by the beginners of L2 writing; but the biggest among them are the blank page, having no or very little interest to write in L2, and the fear about writing in L2 in the minds of students. Thomas (1993) also considers writing in L2 as one of the main problems for L2 learners. He terms lack of interest responsible for this problem. In an interview, presented by Donald (1996), a teacher contends that teachers should give such topics for writing assignment which are linked with their day-today experiences, rather than topic about which they have no idea. Cole and Feng (2015) argue that a good English language teacher endeavors to remove the fear of committing mistakes from the minds of beginners. Confidence must be developed among the beginners of L2 writers and they must be 
allowed to write their first drafts in L2 without thinking of committing mistakes. 'Fluency First Approach' is the term used by MacGowan-Gilhooly (1991) for this approach.

\section{Discussion}

The findings of the study are supported by quite few studies. One of such studies is that of Stewart \& Greg (2013). They are of the view that students' voices are always there, lingering in our memories and shaping our pedagogies. Such voices are best recognized by practices, following Bakhtin's theories of Language. Describing the experience of past students, he presents the example of Reynaldo, who proved very effective in shaping his language pedagogy. The idea presented by Reynaldo, that forced him to continue that practice in future as well was asking every student every week to bring for discussion some personal experiences. Another experience is shared by Stewart. According to him, he realized the importance of dialogic teaching when he reflected back and recalled his experience of dialogic writing with one of his students. That process of engaging in dialogic writing with the student greatly influenced his language pedagogy. Through dialogic writing, the student shared such experience that, in absence of that medium, he would never have disclosed. The findings of the study are also favored by Stewart (2010), who believes that the exploration of dialogic process for instructional purposes can help in the formation of a theoretical framework for pedagogy where students will be active participants rather than passive listener. One of the features of dialogic teaching is that both the students and teachers, in the end, are benefited. Students, on one hand, learn to communicate effectively in L2; while on the other hand it makes a noticeable addition to the experience of English language teachers. Thus the language pedagogy of teachers improves a lot. Engaging in dialogue, across the space and time, with the students made the valuable addition to the researcher's knowledge as well. Bakht, Sabir, and Usman are always there when I enter new class. The very first priority in every new class is to memorize the name of each and every student and address them frequently with their names. A great difference has been observed by me between now and then. Every student is excited and takes keen interest in the classroom activities. A greater part of a problem is solved for an English teacher, when s/he finds students actively participating in the activities. I find Bakht in every face, exclaiming! "I am Bakht and I am very excited". This happened because of the experience of dialogic teaching in the experimental study. Similarly, I always find Sabir, smiling by my side, whenever I plan an activity for improving the writing skill of my students. The response of students, in solving the writing assignments, is very encouraging. Therefore, dialogic teaching has made the valuable addition to my practices of improving the writing skill of my students. Coming across the problem of Usman was quite new experience for me. I did not expect a student of $12^{\text {th }}$ grade reading the books of philosophy to the extent that it would change his thinking. I judged the value of Psychology as a subject during the experimental study. Keeping in view my experience, I can claim that every teacher must have a sufficient knowledge of psychology, otherwise bright students like Usman will be spoiled. It would never have happened, if I had not engaged with Usman in dialogic practice.

Dialogic pedagogy provides such an environment in the classroom where, both, the students and teachers are benefitted. It proves helpful for students, on one hand, to improve effective communication in L2; and on the other hand it enables the teachers to come across such experiences which make valuable addition to their language pedagogy. New lessons learnt during the study contains much food for my future academic career. In the light of the literature above, it can be said that language pedagogy can be effectively re-shaped. If, as ESL teachers, we want to bring the change and strive to shift our pedagogy to a result-oriented one; we must part with the traditional ways and switch over to one, advocated in this study. It advocates a democratic approach where you give weightage to the voice of an important stake holder inside the classroom.

\section{Conclusion}

Dialogic pedagogy presents a suitable alternative to those who are in search of effective methods of teaching English to second language learners. Dialogic teaching is unlike monologic teaching where the teacher is considered as a 'sage on the stage', and the presence of students is never given any value. The change in language pedagogy is possible if English language teachers engage in dialogue with present and past students, across the space and time. In the absence of dialogic practice, we would be living in isolation, away from the possibilities of learning from the experiences of our students. Dialogic teaching ensures that teachers are not alone in the classroom, but are accompanied 
by the students whose experiences may change their language pedagogy. By giving value to the voices of their students, teachers can bring positive changes in their language pedagogy.

\section{Recommendations}

It is high time for English language teachers to adopt dialogic teaching and part their ways with monologic teaching, in order to cater to the growing needs of the students as well teachers. The traditional methods of teaching, in the local context, are producing results neither for teachers nor for ESL students. For those teachers who are not satisfied with their current methods of teaching the English language, dialogic teaching can prove a suitable alternative. It may introduce them to new trends in the teaching which are necessary for their overall growth.

\section{References}

Alaji, C. M; Tijani, S. I., \& Abdullahi, H. O. (2015). Significance of educational psychology for teachers education and national development in Nigeria. Academic Discourse: An International Journal, 8 (1).

Alexander, R. J. (2008). Towards dialogic teaching. Rethinking classroom talk. Cambridge: Dialogos UK Ltd.

Bakhtin, M. M. (1981). The dialogic imagination: Four essays by MM Bakhtin (M. Caryl Emerson, Michael Holquist (Transl.). Austin, Texas: University of Texas.

Bakhtin, M. M. (1986). Speech genres and other late essays, (M. Caryl Emerson and Michael Holquist, trans. Vern W. McGee (Austin: University of Texas Press)

Calderhead, J. (1989). Reflective teaching and teacher education. Teaching and Teacher Education. 5, 43-51.

Celce-Murcia, M. (1991). Teaching English as a second or foreign language. Heinle \& Heinle Publishers, the University of California.

Coia, L., \& Taylor, M. (2009). Co/autoethnography: Exploring our teaching selves collaboratively. In Research Methods for the Self-study of Practice (pp. 3-16). Springer, Dordrecht.

Cole, J., \& Feng, J. (2015). Effective strategies for improving writing skills of Elementary English Language Learners. Online Submission.

Donald, F. (1996). Teacher learning in language teaching. Cambridge University Press.

Freire, P. (2004). Pedagogy of hope: Reliving pedagogy of the oppressed. New York,

NY: Continuum International Publishing Group.

Freire, P. (1970). Pedagogy of the oppressed. New York, NY: Continuum.

Glenz, T. (2014). The Importance of Learning Students' Names. Journal on Best Teaching Practices.1(1), 21-22.

Grinnell, R.M. \& Williams, M. (1990). Research in social work: A primer. Itasca, IL: Peacock.

Gupta, A. \& Lee, G. (2015). Dialogic Teaching Approach with English Language Learners to Enhance Oral Language Skills in the Content Areas. International Journal of Language and Linguistics. 2(5).

Hall, J.K., Vitanova, G., Marchenkova, L. (2005). Dialogue with Bakhtin on Second and Foreign Language Learning New Perspectives. Lawrence Erlbaum Associates, Publishers. London

Hepple, E. (2010). Negotiating teacher identities: Dialogic reflections on classroom interaction in a transnational context (Doctoral dissertation, Griffith University).

Hindman, J. L., Stronge, J. H., \& Tucker, P. D. (2004). Handbook for qualities of effective teachers. United States of America: Association for Supervision \& Curriculum Development.

Holquist, M. (2002). Dialogism. ( $2^{\text {nd }}$ ed). London: Routledge.

Hooks, B (1994). Teaching to transgress. Education as the practice of freedom. New York: Routledge.

Keppel, G., \& Wickens, T. D. (2003). Design and analysis: A researcher's handbook (4th ed.). Englewood Cliffs, NJ: Prentice Hall.

Korthagen, F., \& Vaslos, A. (2005). Levels in reflection: Core reflection as a means to enhance professional growth. Teachers and Teaching: Theory and Practice, 11(1), 47-71.

MacGowan-Gilhooly, A. (1991). Fluency before correctness: A whole language experiment in college ESL. College ESL, 1(1), 37-47. 
Patrick, H., Anderman, L. H., Bruening, P. S., \& Duffin, L. C. (2011). The role of educational psychology in teacher education: Three challenges for educational psychologists. Educational Psychologist, 46(2), 71-83.

Rosenthal, R., \& Rosnow, R. L. (1991). Essentials of behavioral research: Methods and data analysis (Vol. 2). New York: McGraw-Hill.

Russell, T. (2010). Self-study by teacher educators. International encyclopedia of education. 7. 689694

Schoen, D. (1987). Educating the Reflective Practitioner. London: Jossey-Bass.

Seaberg, J.R. (1988). Utilizing sampling procedures. In Grinnell, R.M. (Ed.), Social work

research and evaluation, (3rd ed). Itasca, IL: Peacock.

Stewart, T. T., \& McClure, G. (2013). Freire, Bakhtin, and collaborative pedagogy: A dialogue with students and mentors. International Journal for Dialogical Science, 7(1), 91-108.

Stewart, T. T. (2010). A dialogic pedagogy: Looking to Mikhail Bakhtin for alternatives to standards period teaching practices. Critical Education, 1(6). 1-21.

Syverud, K. D. (1993). Taking Students Seriously: A Guide for New Law Teachers. J. Legal Educ., 43, 247.

Thomas, J. (1993). Countering the 'I can't write English' syndrome. TESOL Journal, 2 12-15.

Tomlinson, C. A. (1999). The differentiated classroom: Responding to the needs of all learners. Alexandria, VA: Association for Supervision and Curriculum Development.

Wright, S. P., Horn, S. P., \& Sanders, W. L. (1997). Teacher and classroom context effects on student achievement: Implications for teacher evaluation. Journal of Personnel Evaluation in Education, 11, 57-67.

Zumwalt, K., \& Craig, E. (2005). Teachers' characteristics: Research on the indicators of quality. Studying teacher education: The report of the AERA panel on research and teacher education, 157-260. 